[Article]

\title{
1-丁腈-3-甲基咪唑双三氟甲基磺酸亚胺的性质
}

\author{
刘青山 ${ }^{1, *}$ 刘 惠 ${ }^{2,3}$ 牟 林 ${ }^{1, *}$ \\ ( ${ }^{1}$ 沈阳农业大学理学院, 沈阳 110866; ${ }^{2}$ 上海环境卫生工程设计院有限公司, 上海 200232; \\ 3 上海污染场地修复工程技术研究中心, 上海 200232)
}

\begin{abstract}
摘要: 制备了功能化离子液体 1-丁腈-3-甲基咪唑双三氟甲基磺酸亚胺。在 $T$ 为 $283.15-353.15 \mathrm{~K}$ 温度范围 内, 测定了该功能化离子液体的密度、动力粘度、电导率及折光率。讨论了亚甲基的增减对该类功能化离子 液体的密度、动力粘度、电导率及折光率等性质的影响, 并与传统咪唑类、吡啶类离子液体物理化学性质的 变化趋势进行了对比。通过经验方程计算了该功能化离子液体的热膨胀系数、分子体积、标准摩尔熵及晶格 能等热力学性质参数。讨论了 Vogel-Fulcher-Tamman (VFT)方程和 Arrhenius 方程的适用性, 得出 VFT方程 适用于该功能化离子液体, 而Arrhenius 方程并不适用。有关研究对新型离子液体的合成及其工业化的应用 具有十分重要的意义。
\end{abstract}

关键词: 功能化离子液体; 密度; 动力粘度; 电导率; 折光率

中图分类号: 0642

\section{Properties of 1-(Cyanopropyl)-3-methylimidazolium Bis[(trifluoromethyl)sulfonyl]imide}

\author{
LIU Qing-Shan ${ }^{1, *} \quad$ LIU Hui ${ }^{2,3} \quad$ MOU Lin ${ }^{1, *}$ \\ ('School of Science, Shenyang Agricultural University, Shenyang 110866, P. R. China; \\ ${ }^{2}$ Shanghai Environmental Sanitation Engineering Design Institute Co., Ltd., Shanghai 200232, P. R. China; \\ ${ }^{3}$ Shanghai Engineering Research Center of Contaminated Sites Remediation, Shanghai 200232, P. R. China)
}

\begin{abstract}
The functional ionic liquid (FIL) 1-(cyanopropyl)-3-methylimidazolium bis[(trifluoromethyl)sulfonyl] imide [PCNMIM][NTf $]$ was synthesized using an ion-exchange method. Density, dynamic viscosity, electrical conductivity, and refractive index were determined in the temperature range $283.15-353.15 \mathrm{~K}$. The effect of methylene group introduction is discussed for the FILs and imidazolium ionic liquids (ILs). The thermal expansion coefficient, molecular volume, standard molar entropy, and lattice energy were determined by the empirical equations from the measurement values. The temperature dependence on electrical conductivity and dynamic viscosity of the FILs were fitted by the Vogel-Fulcher-Tammann (VFT) equation. The adaptability of the Arrhenius equation was also discussed for the electrical conductivity and dynamic viscosity. The study of the thermodynamic properties of the FIL is important for synthesis of new ILs and their application.
\end{abstract}

Key Words: Functional ionic liquid; Density; Dynamic viscosity; Electrical conductivity; Refractive index

\section{Introduction}

Ionic liquids (ILs) have exhibited outstanding physico-chemical properties $^{1-5}$, like good solvation, negligible vapor pressure, good thermal stability, and designability etc. ILs have been applied for

Received: August 3, 2015; Revised: December 17, 2015; Published on Web: December 17, 2015.

*Corresponding authors. LIU Qing-Shan, Email: liuqingshan@dicp.ac.cn; Tel: +86-13478787524. MOU Lin, Email: myname-mulin@tom.com. The project was supported by the National Natural Science Foundation of China (21203193) and Program for Liaoning Excellent Talents in University, China (LJQ2015099).

国家自然科学基金(21203193)和辽宁省高等学校优秀人才支持计划(LJQ2015099)资助

(c) Editorial office of Acta Physico-Chimica Sinica 
industrial and scientific area as the green solvents. The functional ionic liquids (FILs) have been paid much more attention because of the designability ${ }^{6-15}$. The physical chemical properties can be designed according to the introduction of the functional groups, like $-\mathrm{CN},-\mathrm{OH},-\mathrm{CH}_{2}-\mathrm{O}-\mathrm{CH}_{3}$, etc.

Egashira et al. ${ }^{6-8}$ have introduced the cyano group on the imidazolium FILs and quaternary ammonium FILs, respectively. The FILs have been applied in the lithium batteries as electrolyte components. The FILs have showed an improved cycle behavior compared with the electrolyte based on a tetraalkylammonium ionic liquid without a cyano group. The quaternary ammoniumbased FILs containing a cyano group showed the better stability of the cathodic than the imidazolium-based FILs. Hardacre et al. ${ }^{9,10}$ have synthesized two series of pyridinium-based FILs in order to compare the effects of different electron-withdrawing functional groups on their ability to form ionic liquids. The presence of the electron-withdrawing functional groups nitrile or trifluoromethyl substituent on the pyridinium ring leads to salts with higher melting temperature than traditional ILs. On the basis, the authors have observed the liquid charge-transfer complex form on contacting electron-rich aromatics with electron withdrawing group appended 1-alkyl-4-cyanopyridinium ionic liquids. Zhang et al. ${ }^{11}$ have studied the solubilities of $\mathrm{C}_{2} \mathrm{H}_{4}$ and $\mathrm{CO}_{2}$ in the cyano type imidazolium FILs through the gas chromatography. Compared with the 1,3-dialkylimidazolium type ILs, the cyano type FILs result in a remarkable decrease of the interactions of hydrocarbons. The cyano type ILs have exhibited the advantageous properties. As the solvent, it can be applied as suitable reaction media and ligands in catalytic reaction, as electrolyte in lithium battery, as solvent for extraction of metals and dissolution of cellulose.

Although the cyano type FILs have been applied in some area, the physico-chemical properties are not enough for the application. Recently, the 1-(cyanomethyl)-3-methylimidazolium bis[(trifluoromethyl)sulfonyl]imide [MCNMIM] $\left[\mathrm{NTf}_{2}\right]$ has been synthesized in our group ${ }^{12}$. The density, dynamic viscosity, electrical conductivity were determined by the traditional methods. In order to study the effect of the methylene on the properties for the series ILs, the 1- (cyanopropyl)- 3-methylimidazolium bis[(trifluoromethyl)sulfonyl]imide [PCNMIM] $\left[\mathrm{NTf}_{2}\right]$ was synthesized and the properties were determined. The comparison of the propertie was also discussed with the non-functional traditional ILs. The traditional ILs are 1-ethyl-3-methylimidazolium bis[(trifluoromethyl) sulfonyl]imide ([EMIM][NTf $]$ ), 1-butyl-3-methylimidazolium bis [(trifluoromethyl)sulfonyl]imide ([BMIM] $\left.\left[\mathrm{NTf}_{2}\right]\right)$, 1-ethyl-2,3methylimidazolium bis[(trifluoromethyl)sulfonyl]imide ([EM$\left.\mathrm{MIM}]\left[\mathrm{NTf}_{2}\right]\right)$, 1-butyl-2,3-methylimidazolium bis[(trifluoromethyl)sulfonyl]imide ([BMMIM] $\left.\left[\mathrm{NTf}_{2}\right]\right)$. Some of the thermodynamic properties were estimated from the measurement data by the empirical equations. The studies of the above FIL properties are important for the novel IL synthesis and industrial application.

\section{Experimental}

\subsection{Materials}

The putiries, moleculer weight (MW), and company name (Source) of the 1-(cyanomethyl)-3-methylimidazolium cloride ([PCNMIM][Cl]) and lithium bis[(trifluoromethyl)sulfonyl]imide ([Li][NTf $]$ ) are listed in Table S1 of the Supporting Information.

The hydrophobic FIL [PCNMIM] $\left[\mathrm{NTf}_{2}\right.$ ] was obtained in the distilled water by the traditional ion exchange reaction according to the literature ${ }^{12}$. The $[\mathrm{PCNMIM}][\mathrm{Cl}]$ was dissolved by distilled water in flask, the equivalent amount of $\operatorname{LiNTf}_{2}$ salt was added into the flask under stirring. The bottom colorless phase was washed several times with distilled water until no $\mathrm{Cl}^{-}$(it was determined by $\mathrm{AgNO}_{3} / \mathrm{HNO}_{3}$ solution, the content of $\mathrm{Cl}^{-}$was estimated to lower than $0.005 \%$ (in mass fraction). The products were finally dried in high vacuum for $48 \mathrm{~h}$ at $353 \mathrm{~K}$. The FIL [PCNMIM] $\left[\mathrm{NTf}_{2}\right]$ was characterized by ${ }^{1} \mathrm{H} \mathrm{NMR}$ and ${ }^{13} \mathrm{C} \mathrm{NMR}$ spectra (See the Figs.S1 and S2 of the Supporting Information). The final mass fraction and molecular weight of the FIL [PC$\mathrm{NMIM}]\left[\mathrm{NTf}_{2}\right]$ were also listed in Table S1 of the Supporting Information.

In order to compare the differences of the structure, the [PCNMIM] [NTf $]$, [MCNMIM] [NTf $]$, ([EMIM] [NTf $\left.\left.f_{2}\right]\right)$, and $\left([\mathrm{BMIM}]\left[\mathrm{NTf}_{2}\right]\right)$ are presented in Fig.1.

\subsection{Measurements of the density, electrical conductivity, dynamic viscosity, and refractive index}

The weight content of the water was determined by a Cou-Lo Aquamax Karl Fischer moisture meter v.10.06 (Mettler Toledo, Switzerland), and was found to be $<0.02 \%$ (in mass fraction). Recently, Jacquemin et al. ${ }^{16}$ have studied the effect of the water content on the hydrophobic IL [EMIM] $\left[\mathrm{NTf}_{2}\right]$ properties (density and dynamic viscosity) from $0.005 \%$ to $1.98 \%$ (mass fraction). So, the water content can be ignored in this work.

The density, electrical conductivity, dynamic viscosity, and refractive index were determined by a previous method at atmosphere ${ }^{12}$. The uncertainties of the experimental values are also estimated according to literature $\mathrm{e}^{17-20}$.

The density and dynamic viscosity of the FIL [PCNMIM][NTf ${ }_{2}$ ] was determined by a automated SVM3000 Anton Paar rotational Stabinger viscometer-densimeter (Anton Paar GmbH, Austria) with cylinder geometry at $((288.15-338.15) \pm 0.01) \mathrm{K}^{12}$. The principle was based on a modified Couette according to a rapidly rotating outer tube and a relative slowly rotating inner measuring bob. The values were recorded every $5 \mathrm{~K}$ after attaining thermal equilibrium $30 \mathrm{~min}$. The electrical conductivity was carried out on a MP522 conductivity instrument (Shanghai San-Xin Instrumentation, P. R. China) with the cell constants of $1 \mathrm{~cm}^{-1}$ (the cell was calibrated with the aqueous $\mathrm{KCl}$ solution) at $((288.15-338.15) \pm$ $0.05) \mathrm{K}^{12}$. The measurement frequency and voltage of the electrical conductivity were $50 \mathrm{~Hz}$ and $9 \mathrm{~V}$, respectively. The refractive index was carried out according to the literature ${ }^{21}$. The data were carried on an Abbe refractometer (Shanghai Shen Guang Instrument Co., P. R. China) and the frequency was $50 \mathrm{~Hz}$. The degassed water refractive index was determined by the instrument at 
a<smiles>Cn1cc[n+](CCCC#N)c1</smiles>

[PCNMIM][NTf 2$]$

b<smiles></smiles>

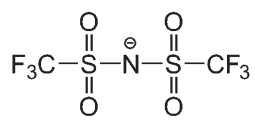

[MCNMIM][NTf

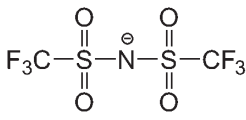<smiles>CCCC[n+]1ccn(C)c1</smiles>

[BMIM][NTf $\left.{ }_{2}\right]$<smiles></smiles><smiles>CS(=O)(=O)N(S(=O)(=O)[SiH3])S(=O)(=O)C(F)(F)F</smiles>

[EMIM][NTf $\left.f_{2}\right]$

Fig.1 Structures of [PCNMIM][NTf $]$, [BMIM][NTf $\left.f_{2}\right]$, [MCNMIM] [NTf $\left.f_{2}\right]$, and [EMIM] $\left[\mathrm{NTf}_{2}\right]$

$(298.15 \pm 0.05) \mathrm{K}$ and the value was in good agreement with the literature $^{22}$. Each value was the average of the three times and the standard uncertainties were $\pm 0.0002 \mathrm{~g} \cdot \mathrm{cm}^{-3}$ for density at 0.65 confidence level, $\pm 1 \%$ for dynamic viscosity at 0.95 confidence level, and $\pm 1 \%$ for dynamic viscosity at 0.95 confidence level. The uncertainty values were estimated from the effect of the machine, room temperature and pressure, water and halogen content etc.

The above experimental values are listed in Table 1.

\section{Results and discussion}

From the Table 1, the value of electrical conductivity is 1.125 $\mathrm{mS} \cdot \mathrm{cm}^{-1}$ for FIL [PCNMIM] $\left[\mathrm{NTf}_{2}\right]$ and the relative deviation is

Table 1 Experimental values of density, $\rho$, dynamic viscosity, $\eta$, electrical conductivity, $\sigma$, and refractive index, $n_{\mathrm{b}}$, of [PCNMIM] [NTf $f_{2}$ from 283.15 to $353.15 \mathrm{~K}$ under atmosphere pressure

\begin{tabular}{ccccc}
\hline$T / \mathrm{K}$ & $\rho /\left(\mathrm{kg} \cdot \mathrm{m}^{-3}\right)$ & $\eta /(\mathrm{mPa} \cdot \mathrm{s})$ & $\sigma /\left(\mathrm{mS} \cdot \mathrm{cm}^{-1}\right)$ & $n_{\mathrm{D}}$ \\
\hline 283.15 & 1529.0 & 612.68 & $0.425^{\mathrm{a}}$ & $1.4421^{\mathrm{a}}$ \\
288.15 & 1523.9 & 419.66 & 0.612 & 1.4412 \\
293.15 & 1519.1 & 303.31 & 0.841 & 1.4400 \\
298.15 & 1514.3 & 222.35 & 1.125 & 1.4387 \\
303.15 & 1509.7 & 166.86 & 1.473 & 1.4373 \\
308.15 & 1505.1 & 131.14 & 1.874 & 1.4360 \\
313.15 & 1500.6 & 99.090 & 2.33 & 1.4349 \\
318.15 & 1496.1 & 78.438 & 2.88 & 1.4339 \\
323.15 & 1491.6 & 63.791 & 3.49 & 1.4328 \\
328.15 & 1487.0 & 55.023 & 4.17 & 1.4317 \\
333.15 & 1482.6 & 44.728 & 4.94 & 1.4306 \\
338.15 & 1478.1 & 37.515 & 5.78 & 1.4296 \\
343.15 & 1473.7 & 29.223 & 6.66 & 1.4285 \\
348.15 & 1469.2 & 26.418 & 7.60 & 1.4275 \\
353.15 & 1464.8 & 23.573 & $8.65^{\mathrm{a}}$ & $1.4262^{\mathrm{a}}$ \\
\hline & & &
\end{tabular}

$6.25 \%$ with the literature value of $1.2 \mathrm{mS} \cdot \mathrm{cm}^{-1}$ at $298.15 \mathrm{~K}^{7}$.

In order to compare the influence of methylene on IL properties, the values of density, dynamic viscosity, and electrical conductivity for three series ILs are listed in Table 2 at $298.15 \mathrm{~K}$. The ILs are [EMIM][NTf $\left.f_{2}\right],[\mathrm{BMIM}]\left[\mathrm{NTf}_{2}\right]$, [EMMIM][NTf $]$ ], [BMMIM] [NTf 2 ], [MCNMIM][NTf 2 , and [PCNMIM] $\left.\mathrm{NTf}_{2}\right]$, respectively.

From Table 2, the three series ILs have exhibited the same tendency for density after the introduction of the methylene on alkyl side chain. Usually, for dynamic viscosity and electrical conductivity, the introduction of the methylene leads to the increase of dynamic viscosity and decrease of electrical conductivity. However, for the two FILs, the values have exhibited the contrary tendency with the traditional ILs. Compared with the literature $^{12}$, the dynamic viscosity values of FIL [PCNMIM] $\left[\mathrm{NTf}_{2}\right]$ are lower than FIL [MCNMIM] $\left[\mathrm{NTf}_{2}\right]$ and the electrical conductivity values of FIL [PCNMIM] $\left[\mathrm{NTf}_{2}\right]$ are higher than FIL $[\mathrm{MCNMIM}]\left[\mathrm{NTf}_{2}\right]$ in the temperature range. The abnormal results have been also discoveried for traditional pyridinium type ILs from our group ${ }^{23-27}$. For the pyridinium type ILs, the electrical conductivity values increase when the methyl group is introduced on position 4 . The dynamic viscosity values decrease when the methyl group is introduced on position 4 . We believe that the groups of the electron withdrawing and electron donating play the important role to the effect of the properties. $-\mathrm{CN}$ is the electron withdrawing group, $-\mathrm{CH}_{2}-$ and $-\mathrm{CH}_{3}$ are the electron donating groups. For the two series ILs, the introduction of the $-\mathrm{CH}_{2}-$ and $-\mathrm{CH}_{3}$ leads to the cation having the relatively symmetry structure. Then, the cation and anion are relatively far away and the force of them becomes weak. So, the ILs exhibit the high fluidity after the introduction of $-\mathrm{CH}_{2}-$ and $-\mathrm{CH}_{3}$.

Based on the same anion, at $298.15 \mathrm{~K}$, the density follows the order of ILs $\left[\mathrm{C}_{4} 4 \mathrm{mpy}\right]\left[\mathrm{NTf}_{2}\right]<[\mathrm{BMMIM}]\left[\mathrm{NTf}_{2}\right]<[\mathrm{BMIM}]$

Table 2 Comparison of density, dynamic viscosity, and electrical conductivity of [EMIM][NTf ${ }_{2}$, [BMIM][NTf $\left.{ }_{2}\right],\left[\mathrm{EMMIM}_{\text {[NTf }}\right.$ ], [BMMIM][NTf ${ }_{2}$, [MCNMIM][NTf ${ }_{2}$ ], and [PCNMIM] $\left[\mathrm{NTf}_{2}\right.$ ] at $298.15 \mathrm{~K}$ under atmosphere pressure

\begin{tabular}{|c|c|c|c|c|c|}
\hline IL & $\mathrm{MW} /\left(\mathrm{g} \cdot \mathrm{mol}^{-1}\right)$ & $V /\left(\mathrm{cm}^{3} \cdot \mathrm{mol}^{-1}\right)$ & $\rho /\left(\mathrm{kg} \cdot \mathrm{m}^{-3}\right)$ & $\eta /(\mathrm{mPa} \cdot \mathrm{s})$ & $\sigma /\left(\mathrm{mS} \cdot \mathrm{cm}^{-1}\right)$ \\
\hline$[\mathrm{EMIM}]\left[\mathrm{NTf}_{2}\right]$ & 391.31 & 257.75 & $1518.2^{\mathrm{a}}$ & $32.0^{\mathrm{a}}$ & $8.96^{\mathrm{a}}$ \\
\hline$[\mathrm{BMIM}]\left[\mathrm{NTf}_{2}\right]$ & 419.36 & 291.91 & $1436.6^{\mathrm{a}}$ & $51.7^{\mathrm{a}}$ & $3.98^{\mathrm{a}}$ \\
\hline$[\mathrm{EMMIM}]\left[\mathrm{NTf}_{2}\right]$ & 405.33 & 271.48 & $1493.1^{a}$ & $72.2^{\mathrm{a}}$ & $3.89^{\mathrm{a}}$ \\
\hline$[\mathrm{BMMIM}]\left[\mathrm{NTf}_{2}\right]$ & 433.38 & 304.70 & $1422.4^{a}$ & $101.6^{\mathrm{a}}$ & $2.12^{\mathrm{a}}$ \\
\hline$[\mathrm{MCNMIM}]\left[\mathrm{NTf}_{2}\right]$ & 402.29 & 249.92 & $1609.7^{\mathrm{b}}$ & $315.5^{\mathrm{b}}$ & $0.919^{b}$ \\
\hline$[\mathrm{PCNMIM}]\left[\mathrm{NTf}_{2}\right]$ & 430.34 & 284.18 & $1514.3^{\mathrm{c}}$ & $222.35^{\mathrm{c}}$ & $1.125^{\mathrm{c}}$ \\
\hline
\end{tabular}


$\left[\mathrm{NTf}_{2}\right]<\left[\mathrm{C}_{4}\right.$ py $]\left[\mathrm{NTf}_{2}\right]<[\mathrm{PCNMIM}]\left[\mathrm{NTf}_{2}\right]$, whereas the experimental density values are $1.5143 \mathrm{~g} \cdot \mathrm{cm}^{-3}$ for [PCNMIM] [NTf $]$ ], $1.4366 \mathrm{~g} \cdot \mathrm{cm}^{-3}$ for [BMIM] $\left[\mathrm{NTf}_{2}\right]^{28}, 1.4224 \mathrm{~g} \cdot \mathrm{cm}^{-3}$ for [BMMIM] $\left[\mathrm{NTf}_{2}\right]^{28}, 1.4547 \mathrm{~g} \cdot \mathrm{cm}^{-3}$ for 1-ethylpyridinium bis[(trifluoromethyl) sulfonyl]imide $\left[\mathrm{C}_{4} \mathrm{py}\right]\left[\mathrm{NTf}_{2}\right]^{25}$, and $1.4187 \mathrm{~g} \cdot \mathrm{cm}^{-3}$ for 4-methyl-1butylpyridinium bis[(trifluoromethyl)sulfonyl]imide [ $\left.\mathrm{C}_{4} 4 \mathrm{mpy}\right]$ $\left[\mathrm{NTf}_{2}\right]^{26}$, The dynamic viscosity follows the order of ILs [BMIM] $\left[\mathrm{NTf}_{2}\right]<\left[\mathrm{C}_{4} 4 \mathrm{mpy}\right]\left[\mathrm{NTf}_{2}\right]<\left[\mathrm{C}_{4} \mathrm{py}\right]\left[\mathrm{NTf}_{2}\right]<[\mathrm{BMMIM}]\left[\mathrm{NTf}_{2}\right]<$ $[\mathrm{PCNMIM}]\left[\mathrm{NTf}_{2}\right]$, whereas the values are $222.35 \mathrm{mPa} \cdot \mathrm{s}$ for [PCNMIM][NTf 2$], 51.7 \mathrm{mPa} \cdot \mathrm{s}$ for $[\mathrm{BMIM}]\left[\mathrm{NTf}_{2}\right]^{28}, 101.6 \mathrm{mPa} \cdot$ $\mathrm{s}$ for $[\mathrm{BMMIM}]\left[\mathrm{NTf}_{2}\right]^{28}, 58.3 \mathrm{mPa} \cdot \mathrm{s}$ for $\left[\mathrm{C}_{4} \mathrm{py}\right]\left[\mathrm{NTf}_{2}\right]^{27}$, and $55.14 \mathrm{mPa} \cdot \mathrm{s}$ for $\left[\mathrm{C}_{4} 4 \mathrm{mpy}\right]\left[\mathrm{NTf}_{2}\right]{ }^{26}$. The electrical conductivity follows the order of ILs $[\mathrm{PCNMIM}]\left[\mathrm{NTf}_{2}\right]<\left[\mathrm{C}_{4}\right.$ py $]\left[\mathrm{NTf}_{2}\right]<$ $[\mathrm{BMMIM}]\left[\mathrm{NTf}_{2}\right]<\left[\mathrm{C}_{4} 4 \mathrm{mpy}\right]\left[\mathrm{NTf}_{2}\right]<[\mathrm{BMIM}]\left[\mathrm{NTf}_{2}\right]$, whereas the values are $1.125 \mathrm{mS} \cdot \mathrm{cm}^{-1}$ for [PCNMIM] $\left[\mathrm{NTf}_{2}\right.$ ], $2.12 \mathrm{mS} \cdot$ $\mathrm{cm}^{-1}$ for $[\mathrm{BMMIM}]\left[\mathrm{NTf}_{2}{ }^{28}, 3.98 \mathrm{mS} \cdot \mathrm{cm}^{-1}\right.$ for $[\mathrm{BMIM}]\left[\mathrm{NTf}_{2}\right]^{28}$, $1.67 \mathrm{mS} \cdot \mathrm{cm}^{-1}$ for $\left[\mathrm{C}_{4} \mathrm{py}\right]\left[\mathrm{NTf}_{2}\right]^{27}$, and $3.41 \mathrm{mS} \cdot \mathrm{cm}^{-1}$ for $\left[\mathrm{C}_{4} 4 \mathrm{mpy}\right]$ $\left[\mathrm{NTf}_{2}\right]^{26}$.

From the above result, the introduction of the $-\mathrm{CN}$ functional group on imidazolium ring leads to the density and dynamic viscosity increasing, electrical conductivity decreasing. The reason of the above result may be the increasing of the van der Waals force between the functional group with cation or anion and insufficient side-chain mobility. The effect order of the interaction force is $-\mathrm{CN}>-\mathrm{CH}_{3}$.

The temperatures dependences on density, electrical conductivity, dynamic viscosity, and refractive index of the FIL [PCNMIM] $\left[\mathrm{NTf}_{2}\right]$ are plotted in Figs.2 and 3. From the Fig.2, it can be seen that the lines of density and refractive are linear one with the increasing of the temperature. From the Fig.3, the electrical conductivity and dynamic viscosity exhibite non-linear one with temperature increasing.

\subsection{Density}

From Fig.2, the $\ln \rho$ vs $T$ can be fitted according to the following straight line. The thermal expansion coefficient, $\alpha$, can be obtained.

$$
\ln \rho=b-\alpha T
$$

herein, $\rho$ is the density values, $b$ is an empirical constant, $\alpha$ is the thermal expansion coefficient, $T$ is the experimeantal temperature. The thermal expansion coefficient is $6.09 \times 10^{-4} \mathrm{~K}^{-1}$. The value is in the range of $5 \times 10^{-4}$ and $7 \times 10^{-4} \mathrm{~K}^{-1}$ which obtained by Jacquemin et al. ${ }^{16}$.

According to Glasser ${ }^{29}$, the empirical equations are used for estimation of the molecular volume, $V_{\mathrm{m}}$, standard molar entropy, $S^{0}$, and lattice energy, $U_{\text {Рот }}$ from density values.

$$
\begin{aligned}
& V_{\mathrm{m}}=M /(N \cdot \rho) \\
& S^{0}=1246.5 V_{\mathrm{m}}+29.5 \\
& U_{\text {РОт }}=1981.2(\rho / M)^{1 / 3}+103.8
\end{aligned}
$$

herein, $M$ is molar mass, $N$ is Avogadro's constant, The calculated values of the above are $0.4721 \mathrm{~nm}^{3}$ for molecular volume, 617.9 $\mathrm{J} \cdot \mathrm{K}^{-1} \cdot \mathrm{mol}^{-1}$ for standard molar entropy, and $405 \mathrm{~kJ} \cdot \mathrm{mol}^{-1}$ for lattice energy, respectively. Accoring to the literature ${ }^{12}$, the value of the molecular volume is $0.4151 \mathrm{~nm}^{3}$. The contribution of the

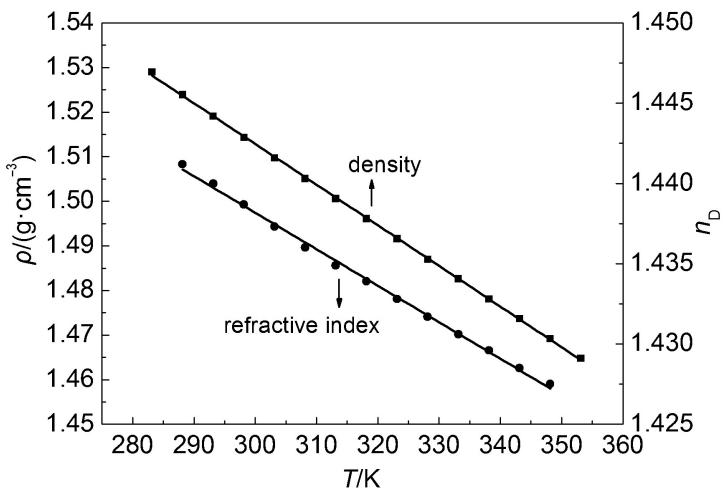

Fig.2 Density and refractive index $v s$ temperature plots for FIL [PCNMIM] [NTf $f_{2}$

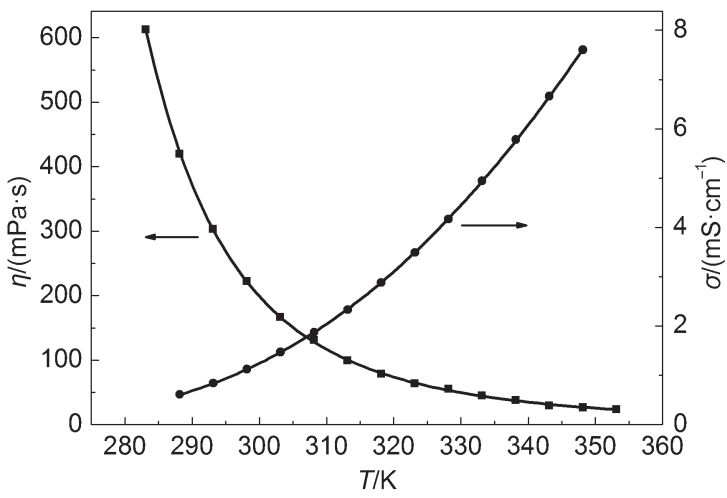

Fig.3 Dynamic viscosity and electrical conductivity $v s$ temperature plots for [PCNMIM][NTf $f_{2}$

methylene to the molecular volume is $0.0285 \mathrm{~nm}^{3}$ for the cyano type FILs. The value is in good agreement with the reported values of $0.0277 \mathrm{~nm}^{3}$ for $\left[\mathrm{C}_{n} 3 \mathrm{mpy}\right]\left[\mathrm{NTf}_{2}\right](n=3,4,6)^{23}, 0.0289 \mathrm{~nm}^{3}$ for $\left[\mathrm{C}_{n} 4 \mathrm{mpy}\right]\left[\mathrm{NTf}_{2}\right](n=2,4,6){ }^{23}, 0.0280 \mathrm{~nm}^{3}$ for ILs [C $\left.\mathrm{C}_{n} \mathrm{py}\right]$ $\left[\mathrm{NTf}_{2}\right]^{24,30}, 0.0282 \mathrm{~nm}^{3}$ for $\left[\mathrm{C}_{n} \operatorname{mim}\right]\left[\mathrm{NTf}_{2}\right]^{29}$, and $0.0279 \mathrm{~nm}^{3}$ for Amino acid at $298.15 \mathrm{~K}^{31-34}$. The lattice energy is much lower than traditional salts, like $U_{\mathrm{POT}, \mathrm{Csl}}=613 \mathrm{~kJ} \cdot \mathrm{mol}^{-122}$. Usually, the ILs exhibit the low lattice energy $y^{23-34}$. And it is the reason that the ILs have the relatively low melting temperature, can exist as liquid state at room temperature.

\subsection{Molar electrical conductivity}

The molar electrical conductivities can be calculated from density and electrical conductivity by the following equation:

$$
\Lambda=\sigma M \rho^{-1}
$$

where $\Lambda$ is the molar electrical conductivity, $\sigma$ is the electrical conductivity, $M$ is the molar mass, and $\rho$ is the density. The molar electrical conductivity values are listed in Table 3.

\subsection{Electrical conductivity}

Recently, Vila et al. ${ }^{35}$ have built the relationaship of the VogelFulcher-Tamman (VFT) and Arrhenius equations as the modified VFT equation. The electrical conductivity activation energies for the four FILs can be calculated by the modified VFT equation. The VFT equation, Arrhenius equation, and modified VFT equation are below: 
Table 3 Calculated values of molar electrical conductivity [PCNMIM] [NTf ${ }_{2}$ ] at 288.15-338.15 $\mathrm{K}$ under atmospheric pressure

\begin{tabular}{cccc}
\hline$T / \mathrm{K}$ & $\Lambda /\left(\mathrm{S} \cdot \mathrm{cm}^{2} \cdot \mathrm{mol}^{-1}\right)$ & $T / \mathrm{K}$ & $\Lambda /\left(\mathrm{S} \cdot \mathrm{cm}^{2} \cdot \mathrm{mol}^{-1}\right)$ \\
\hline 283.15 & 0.119 & 323.15 & 1.007 \\
288.15 & 0.173 & 328.15 & 1.207 \\
293.15 & 0.238 & 333.15 & 1.434 \\
298.15 & 0.320 & 338.15 & 1.683 \\
303.15 & 0.420 & 343.15 & 1.945 \\
308.15 & 0.536 & 348.15 & 2.226 \\
313.15 & 0.668 & 353.15 & 2.541 \\
318.15 & 0.828 & & \\
\hline
\end{tabular}

The uncertainties are $\pm 0.001 \mathrm{mS} \cdot \mathrm{cm}^{2} \cdot \mathrm{mol}^{-1}$ for molar electrical conductivity and $\pm 0.05 \mathrm{~K}$ for temperature at 0.95 confidence level.

$$
\begin{aligned}
& \sigma=\sigma_{0} \exp \left(-B /\left(T-T_{0}\right)\right) \\
& \sigma=\sigma_{\infty} \exp \left(-E_{\sigma} /\left(k_{\mathrm{B}} T\right)\right) \\
& \sigma=\sigma_{\infty} \exp \left(-E_{\sigma} /\left(k_{\mathrm{B}}\left(T-T_{0}\right)\right)\right.
\end{aligned}
$$

here $\sigma$ is the electrical conductivity; $\sigma_{0}, B$ are fitting parameters; $E_{\sigma}$ is the activation energy, which indicates the energy needed for an ion to hop to a free hole; $\sigma_{\infty}$ is the maximum electrical conductivity, $k_{\mathrm{B}}$ is the Boltzmann constant, $\sigma_{0}=\sigma_{\infty}$, and $B=E_{\sigma} / k_{\mathrm{B}}$.

The fitted equation is $\sigma=491.6 \exp (661.8 /(T+189.3))$ by the equation (6). And the correlation coefficient, $R$, is 0.99997 , which indicates that the VFT equation can be well used for the electrical conductivity fitting. The calculated value of electrical conductivity activation energy is $57.1 \mathrm{~kJ} \cdot \mathrm{mol}^{-1}$ for FIL [PCNMIM] [NTf $\mathrm{N}_{2}$ ] according to equation (8). According to literature ${ }^{12}$, the electrical conductivity activation energies are $53.6 \mathrm{~kJ} \cdot \mathrm{mol}^{-1}$ for FIL [MCNMIM] $\left[\mathrm{NTf}_{2}\right]$ and $47.6 \mathrm{~kJ} \cdot \mathrm{mol}^{-1}$ for FIL [EOHMIM] $\left[\mathrm{NTf}_{2}\right]$, respectively. The FIL [PCNMIM] $\left[\mathrm{NTf}_{2}\right]$ exhibits the highest energy than other two FILs [MCNMIM] $\left[\mathrm{NTf}_{2}\right.$ ] and [EOHMIM] $\left[\mathrm{NTf}_{2}\right]$.

By the Arrhenius equation, the $\ln \sigma v s 1000 / T$ was plotted for the FIL in Fig.4.

\subsection{Dynamic viscosity}

Like the electrical conductivity, the VFT equation, Arrhenius equation, and modified VFT equation are below:

$$
\begin{aligned}
& \eta=\eta_{0} \exp \left(B /\left(T-T_{0}\right)\right) \\
& \eta=\eta_{\infty} \exp \left(E_{\eta} /\left(k_{\mathrm{B}} T\right)\right) \\
& \eta=\eta_{\infty} \exp \left(E_{\mathrm{a}} /\left(k_{\mathrm{B}}\left(T-T_{0}\right)\right)\right.
\end{aligned}
$$

where $\eta$ is the dynamic viscosity; $\eta_{0}, B$ are fitting parameters; $E_{\eta}$ is the activation energy for dynamic viscosity; $\eta_{\infty}$ is the maximum dynamic viscosity, $k_{\mathrm{B}}$ is the Boltzmann constant, $\eta_{0}=\sigma_{\infty}$, and $B=$ $E_{\eta} / k_{\mathrm{B}}$.

The best fitted equation is $\eta=0.16 \exp (882.1 /(T+176.2))$ by the equation (9). And the correlation coefficient, $R$, is 0.99989 , which indicates that the VFT equation can also be used for the dynamic viscosity fitting. The dynamic viscosity activation energy can also be calculated and the value is $76.1 \mathrm{~kJ} \cdot \mathrm{mol}^{-1}$ for FIL [PCNMIM] $\left[\mathrm{NTf}_{2}\right]$ according to equation (11). According to literature $^{12}$, the dynamic viscosity activation energies are $62.9 \mathrm{~kJ}$. $\mathrm{mol}^{-1}$ for FIL [MCNMIM] $\left[\mathrm{NTf}_{2}\right.$ ] and $59.7 \mathrm{~kJ} \cdot \mathrm{mol}^{-1}$ for FIL [EOHMIM] $\left.\mathrm{NTf}_{2}\right]$, respectively. Like the electrical conductivity activation energies, the FIL [PCNMIM] $\left[\mathrm{NTf}_{2}\right]$ have also exhibited

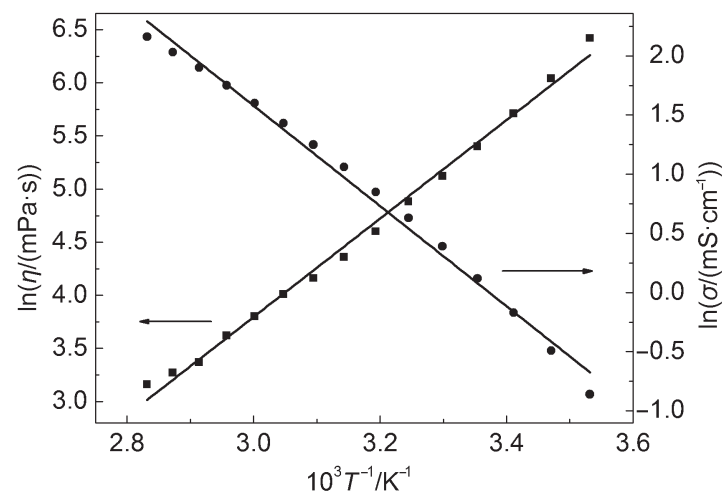

Fig.4 Plots of $\ln \eta$ and $\ln \sigma v s$ 1000/T for FIL [PCNMIM][NTf $\left.]_{2}\right]$

the highest energy than other two FILs $[\mathrm{MCNMIM}]\left[\mathrm{NTf}_{2}\right]$ and [EOHMIM][NTf ${ }_{2}$.

According to equation (10), the $\ln \eta v s 1000 T^{-1}$ was also described in Fig.4 like electrical conductivity for the FIL [PCNMIM] [NTf $\mathrm{NT}_{2}$.

In Fig.4, the black lines are straight lines for fitting of $\ln \sigma v s$ $1000 T^{-1}$ and $\ln \eta v_{s} 1000 T^{-1}$. From the Fig.4, the experimental points are distributed on both sides of the black straight lines. It indicated that the Arrhenius equation is not well fit for the fitting of the electrical conductivity and dynamic viscosity on temperature.

\subsection{Walden product}

The relationship of molar conductivity and dynamic viscosity can be built by the following Walden equation:

$$
\begin{aligned}
& \Lambda \eta^{\alpha}=k \\
& \lg \Lambda=\lg k+\alpha \lg \eta^{-1}
\end{aligned}
$$

where $\alpha$ is the fitting parameter, $k$ is a temperature dependent constant. The description of $\lg \Lambda v_{s} \lg \eta^{-1}$ is shown in Fig.5 for the FIL [PCNMIM] $\left[\mathrm{NTf}_{2}\right.$ ] from 283.15 to $353.15 \mathrm{~K}$. The slope, $\alpha$, can be obtained and the value is 0.927 for FIL [PCNMIM] [NTf 2 ]. In order to compare the relationship, the five others imidazolium type $\mathrm{ILs}^{12,23}$ are also ploted at $298.15 \mathrm{~K}$ in Fig.5. The solid straight line is the ideal line for aqueous $\mathrm{KCl}$ solutions ${ }^{36}$.

From Fig.5, like the others five ILs, the Walden point of the FIL $[\mathrm{PCNMIM}]\left[\mathrm{NTf}_{2}\right]$ is below and close to the ideal line, so, the the FIL $[\mathrm{PCNMIM}]\left[\mathrm{NTf}_{2}\right]$ is also called "subionic" ${ }^{37}$. It means that the FIL [PCNMIM] $\left[\mathrm{NTf}_{2}\right]$ did not yield the expected conductivity from the high fluidities because on average the proton transfer is incomplete $^{37}$. From the Fig.5, the Walden points have exhibited the different change tendency for the three series ILs at $298.15 \mathrm{~K}$. For the traditional ILs, the Walden points of [BMIM] $\left[\mathrm{NTf}_{2}\right]$ and $[\mathrm{BMMIM}]\left[\mathrm{NTf}_{2}\right]$ are lower than [EMIM] $\left[\mathrm{NTf}_{2}\right]$ and [EMMIM] $\left[\mathrm{NTf}_{2}\right]$ following the ideal line, respectively. However, the FIL is reversible, the Walden point of [MCNMIM] $\left[\mathrm{NTf}_{2}\right]$ is lower than [PCNMIM] $\left[\mathrm{NTf}_{2}\right]$. We think that the FIL $[\mathrm{PCNMIM}]\left[\mathrm{NTf}_{2}\right]$ has a better fluidity than [MCNMIM][NTf 2 . The result can also be explained according to the dynamic viscosity and electrical conductivity. Compared with the literature ${ }^{12}$, the dynamic viscosity values of FIL [PCNMIM] $\left[\mathrm{NTf}_{2}\right.$ ] are lower than FIL [MCNMIM] $\left[\mathrm{NTf}_{2}\right]$ and the electrical conductivity values of FIL [PCNMIM] 


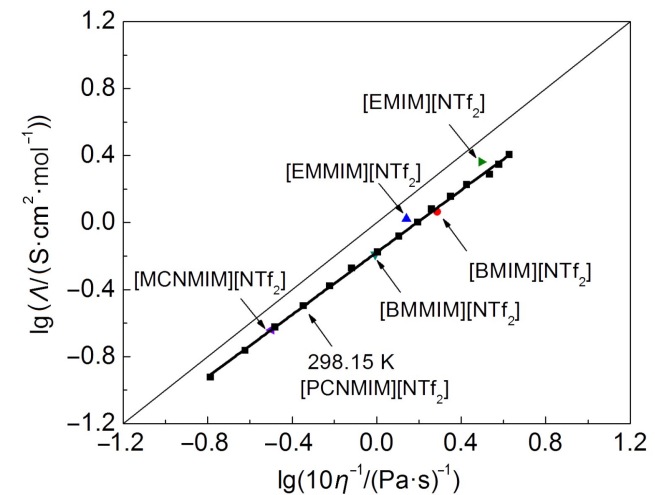

Fig.5 Plot of $\lg \Lambda v s \lg \eta^{-1}$ for the FIL [PCNMIM] $\left[\mathrm{NTf}_{2}\right]$ in the whole measurement temperature with other imidazolium type ILs at $298.15 \mathrm{~K}$

The solid straight line is the ideal line for aqueous $\mathrm{KCl}$ solutions.

$\left[\mathrm{NTf}_{2}\right]$ are higher than FIL $[\mathrm{MCNMIM}]\left[\mathrm{NTf}_{2}\right]$ in the temperature range.

\subsection{Refractive index}

The relationship of refractive index and temperature can also be described for the FIL [PCNMIM] $\left[\mathrm{NTf}_{2}\right]$ by a linear equation:

$$
n_{\mathrm{D}}=A+B T
$$

where $n_{\mathrm{D}}$ is the refractive index; $A, B$ are fitting parameters; $T$ is experimental temperature. The fitted linear equation is $n_{\mathrm{D}}=1.5064-$ $2.27 \times 10^{4} T$. The correlation coefficient is 0.997 from the experimental values. It indicates that the linear equation is fit for the fitting of the refractive index on temperature.

\section{Conclusions}

The density, electrical conductivity, dynamic viscosity, and refractive index of the FIL [PCNMIM] $\mathrm{NTf}_{2}$ ] were determined at atmospheric pressure at $283.15-353.15 \mathrm{~K}$. The FIL [PCNMIM] [ $\left.\mathrm{NTf}_{2}\right]$ exhibited the lower lattice energies than the traditional melt salts, it is the reason that the ionic liquid is liquid at room temperature. The dynamic viscosity of [PCNMIM] $\left[\mathrm{NTf}_{2}\right]$ is lower than [MCNMIM] $\left[\mathrm{NTf}_{2}\right]$ and the electrical conductivity of $[\mathrm{PCNMIM}]\left[\mathrm{NTf}_{2}\right]$ is higher than [MCNMIM] $\left[\mathrm{NTf}_{2}\right]$. The FIL [PCNMIM] $\left[\mathrm{NTf}_{2}\right.$ ] exhibits a better fluidity than [MCNMIM] [NTf $f_{2}$, it is reversible with the traditional imidazolium type ionic liquids. The VFT equation can be well used for fitting of the electrical conductivity and dynamic viscosity on temperature, however, the Arrhenius equation not fit. The temperature dependence on refractive index can be well fitted by the linear equation. The property study of the FIL [PCNMIM] $\left[\mathrm{NTf}_{2}\right]$ will be significant for industrial and engineering applications.

Supporting Information: The ${ }^{1} \mathrm{H}$ NMR and ${ }^{13} \mathrm{C}$ NMR spectra have been included. This information is available free of charge via the internet at http://www.whxb.pku.edu.cn.

\section{References}

(1) Welton, T. Chem. Rev. 1999, 99, 2071. doi: 10.1021/cr980032t

(2) Rantwijk, F. V.; Sheldon, R. A. Chem. Rev. 2007, 107, 2757. doi: $10.1021 / \mathrm{cr} 050946 \mathrm{x}$

(3) Greaves, T. L.; Drummond, C. J. Chem. Rev. 2008, 108, 206. doi: $10.1021 / \mathrm{cr} 068040 \mathrm{u}$

(4) Hapiot, P.; Lagrost, C. Chem. Rev. 2008, 108, 2238. doi: $10.1021 / \mathrm{cr} 0680686$

(5) Jessop, P. G.; Subramaniam, B. Chem. Rev. 2007, 107, 2666. doi: $10.1021 / \mathrm{cr} 0401990$

(6) Egashira, M.; Okada, S; Yamaki, S. J. I.; Dri, D. A.; Bonadies, F.; Scrodati, B. J. Power Sources 2004, 138, 240. doi: 10.1016/ j.jpowsour.2004.06.022

(7) Egashira, M.; Todo, H.; Yoshimoto, N; Morita, N. M.; Yamaki, J. I. J. Power Sources 2007, 174, 560. doi: 10.1016/j. jpowsour.2007.06.123

(8) Egashira, M.; Nakagawa, M.; Watanabe, I.; Okada, S.; Yamaki, J. I. J. Power Sources 2005, 146, 685. doi: 10.1016/j. jpowsour.2005.03.069

(9) Hardacre, C.; Holbrey, J. D.; Mullan, C. L.; Nieuwenhuyzen, M.; Reichert, W. M.; Seddon, K. R.; Teat, S. J. New J. Chem. 2008, 32, 1953. doi: 10.1039/b805063e

(10) Hardacre, C.; Holbrey, J. D.; Mullan, C. L.; Nieuwenhuyzen, M.; Youngs, T. G. A.; Bowron, D. T.; Teat, S. J. Phys. Chem. Chem. Phys. 2010, 12, 1842. doi: 10.1039/b921160h

(11) Zhang, J.; Zhang, Q.; Qiao, B.; Deng, Y. J. Chem. Eng. Data 2007, 52, 2277. doi: 10.1021/je700297c

(12) Liu, Q. S.; Liu, J.; Liu, X. X.; Zhang, S. T. J. Chem. Thermodyn. 2015, 90, 39. doi: 10.1016/j.jct.2015.06.010

(13) Bates, E. D.; Mayton, R. D.; Ntai, I.; Davis, J. H., Jr. J. Am. Chem. Soc. 2002, 124, 926. doi: 10.1021/ja017593d

(14) Cai, Y.; Peng, Y.; Song, G. Catal. Lett. 2006, 109, 61. doi: $10.1007 / \mathrm{s} 10562-006-0057-3$

(15) Hu, S.; Jiang, T.; Zhang, Z.; Zhu, A.; Han, B.; Song, J.; Xie, Y.; Li, W. Tetrahedron Lett. 2007, 48, 5613. doi: 10.1016/j. tetlet.2007.06.051

(16) Jacquemin, J.; Husson, P.; Padua, A. A. H.; Majer, V. Green Chem. 2006, 8, 172. doi: 10.1039/B513231B

(17) Chen, Y.; Zhuo, K.; Chen, J.; Bai, G. J. Chem. Thermodyn. 2015, 86, 13. doi: 10.1016/j.jct.2015.02.017

(18) Chen, Y.; Zhang, H.; Li, A.; Zhuo, K. Fluid Phase Equilibr. 2015, 388, 78. doi: 10.1016/j.fluid.2014.12.038

(19) Wei, J.; Chang, C.; Zhang, Y. Y.; Hou, S. Y.; Fang, D. W.; Guan, W. J. Chem. Thermodyn. 2015, 90, 310. doi: 10.1016/j. jct.2015.04.029

(20) Ma, X. X.; Wei, J.; Guan, W.; Pan, Y.; Zheng, L.; Wu, Y.; Yang, J. Z. J. Chem. Thermodyn. 2015, 89, 51. doi: 10.1016/j. jct.2015.02.025

(21) Tong, J.; Hong, M.; Chen, Y.; Wang, H.; Guan, W.; Yang, J. Z. J. Chem. Thermodyn. 2012, 54, 352. doi: 10.1016/j. jct.2012.05.012

(22) Lide, D. R. Handbook of Chemistry and Physics, 82nd ed.; CRC Press: Boca Raton, FL, 2001-2002.

(23) Liu, Q. S.; Li, P. P.; Welz-Biermann, U.; Chen, J.; Liu, X. X. 
J. Chem. Thermodyn. 2013, 66, 88. doi: 10.1016/j. jct.2013.06.008

(24) Liu, Q. S.; Yang, M.; Yan, P. F.; Liu, X. M.; Tan, Z. C.; WelzBiermann, U. J. Chem. Eng. Data 2010, 55, 4928. doi: 10.1021/je100507n

(25) Liu, Q. S.; Li, P. P.; Welz-Biermann, U.; Liu, X. X.; Chen, J. J. Chem. Eng. Data 2012, 57, 2999. doi: 10.1021/je3004645

(26) Liu, Q. S.; Yan, P. F.; Yang, M.; Tan, Z. C.; Li, C. P.; WelzBiermann, U. Acta Phys. -Chim. Sin. 2011, 27, 2762. [刘青山, 颜佩芳, 杨 沝, 谭志诚, 李长平, Welz-Biermann U. 物理化 学学报, 2011, 27, 2762.] doi: 10.3866/PKU.WHXB20112762

(27) Zhang, Q. G.; Wei, Y.; Sun, S. S.; Wang, C.; Yang, M.; Liu, Q. S.; Gao, Y. A. J. Chem. Eng. Data 2012, 57, 2185. doi: 10.1021/je300153f

(28) Cheng, Z.; Lee, J. M. J. Phys. Chem. B 2014, 118, 2712. doi: 10.1021/jp411904w

(29) Glasser, L. Thermochim. Acta 2004, 421, 87. doi: 10.1016/j. tca.2004.03.015

(30) Liu, Q. S.; Yang, M.; Li, P. P.; Sun, S. S.; Welz-Biermann, U.;
Tan, Z. C.; Zhang, Q. G. J. Chem. Eng. Data 2011, 56, 4094. doi: $10.1021 / \mathrm{je} 200534 \mathrm{~b}$

(31) Fang, D. W.; Tong, J.; Guan, W.; Wang, H.; Yang, J. Z. J. Phys. Chem. B 2010, 114, 13808. doi: 10.1021/jp107452q

(32) Fang, D. W.; Guan, W.; Tong, J.; Wang, Z. W.; Yang, J. Z. J. Phys. Chem. B 2008, 112 7499. doi: 10.1021/jp801269u

(33) Tong, J.; Song, B.; Wang, C. X.; Li, L.; Guan, W.; Fang, D. W.; Yang, J. Z. Ind. Eng. Chem. Res. 2011, 50, 2418. doi: 10.1021/ ie101903t

(34) Xu, W. G.; Ma, X. X.; Li, L.; Tong, J.; Guan, W. Ind. Eng. Chem. Res. 2012, 51, 4105. doi: 10.1021/ie201530b

(35) Vila, J.; Ginés, P.; Pico, J. M.; Franjo, C.; Jiménez, E.; Varela, L. M.; Cabeza, O. Fluid Phase Equilibr. 2006, 242, 141. doi: 10.1016/j.fluid.2006.01.022

(36) Schreiner, C.; Zugmann, S.; Hartl, R.; Gores, H. J. J. Chem. Eng. Data 2010, 55, 1784. doi: 10.1021/je900878j

(37) Belieres, J. P.; Angell, C. A. J. Phys. Chem. B 2007, 111, 4926. doi: 10.1021/jp067589u 
Supporting Information for Acta Phys. -Chim. Sin. 2016, 32 (3), 617-623

doi: 10.3866/PKU.WHXB201512171

\title{
1-丁腈-3-甲基咪唑双三氟甲基磺酸亚胺的性质
}

\author{
刘青山 ${ }^{1, *} \quad$ 刘 惠 ${ }^{2,3}$ 牟 林 ${ }^{1, *}$ \\ ( ${ }^{1}$ 沈阳农业大学理学院, 沈阳 110866; ${ }^{2}$ 上海环境卫生工程设计院有限公司, 上海 200232; \\ ${ }^{3}$ 上海污染场地修复工程技术研究中心, 上海 200232$)$
}

\section{Properties of 1-(Cyanopropyl)-3-methylimidazolium Bis[(trifluoromethyl)sulfonyl]imide}

\author{
LIU Qing-Shan ${ }^{1, *} \quad$ LIU Hui ${ }^{2,3} \quad$ MOU Lin ${ }^{1, *}$ \\ ( ${ }^{1}$ School of Science, Shenyang Agricultural University, Shenyang 110866, P. R. China; \\ ${ }^{2}$ Shanghai Environmental Sanitation Engineering Design Institute Co., Ltd., Shanghai 200232, P. R. China; \\ ${ }^{3}$ Shanghai Engineering Research Center of Contaminated Sites Remediation, Shanghai 200232, P. R. China)
}

*Corresponding authors. LIU Qing-Shan, Email: liuqingshan@dicp.ac.cn; Tel: +86-13478787524.

MOU Lin, Email: myname-mulin@tom.com. 
Table S1 The purity (by mass), molecular weight (MW), and company name (Source) of the [PCNMIM][Cl], [Li][NTf $\left.{ }_{2}\right]$, and [PCNMIM] $\left[\mathrm{NTf}_{2}\right]$

\begin{tabular}{cccc}
\hline Name & Purity (by mass) & MW & Source \\
\hline$[\mathrm{PCNMIM}][\mathrm{Cl}]$ & $\geq 0.99 \%$ & 185.64 & $\begin{array}{c}\text { Lanzhou Institute of } \\
\text { Chemical Physics }\end{array}$ \\
{$[\mathrm{Li}]\left[\mathrm{NTf}_{2}\right]$} & $\geq 0.99 \%$ & 287.09 & $\begin{array}{c}\text { Solvay (ZhenJiang) } \\
\text { Chemicals Co., LTD }\end{array}$ \\
{$[\mathrm{PCNMIM}]\left[\mathrm{NTf}_{2}\right]$} & $\geq 0.99 \%$ & 430.35 & \\
\hline
\end{tabular}

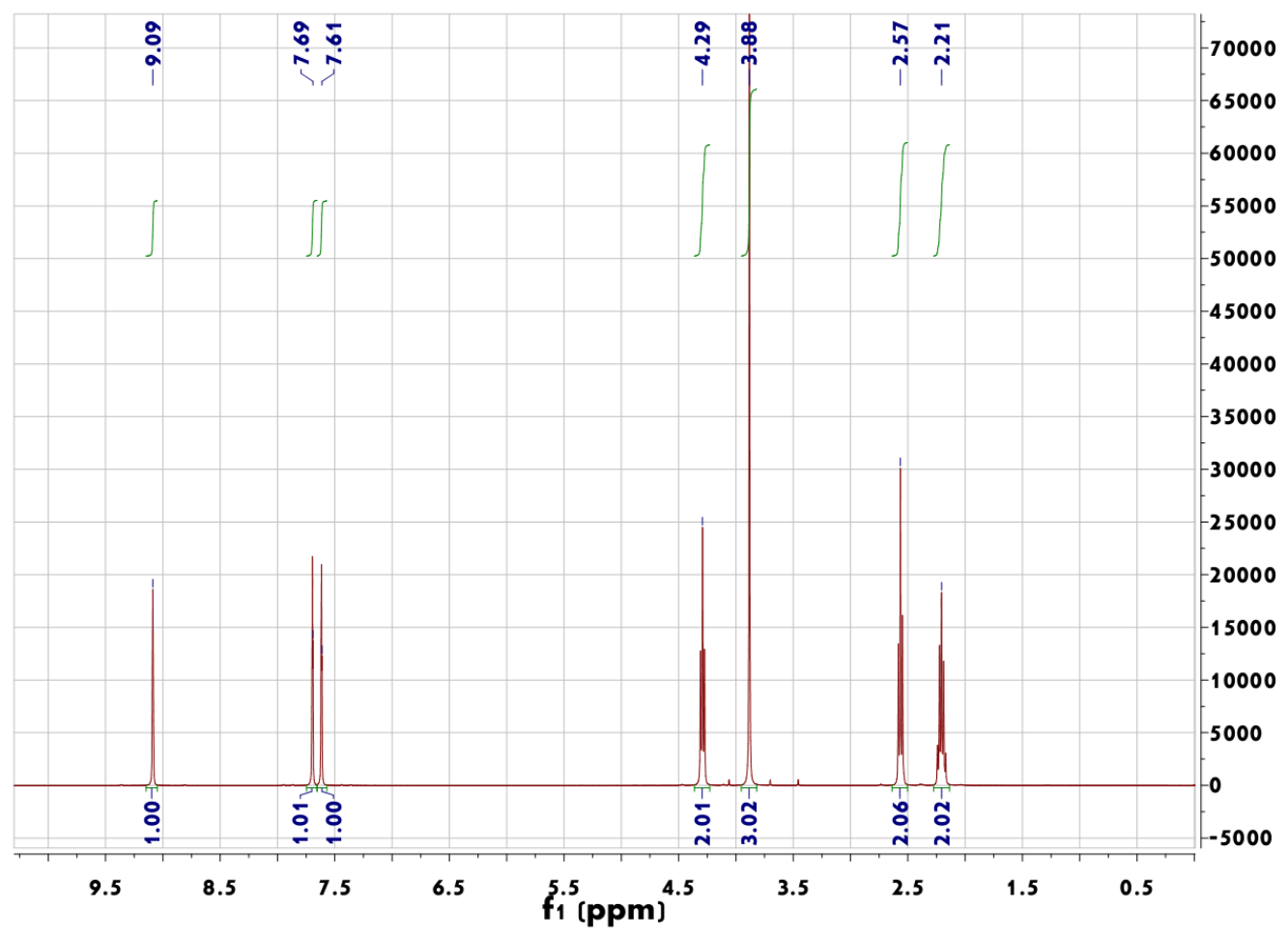

Fig.S1 ${ }^{1}$ H NMR of [PCNMIM] $\left[\mathrm{NTf}_{2}\right]$ 


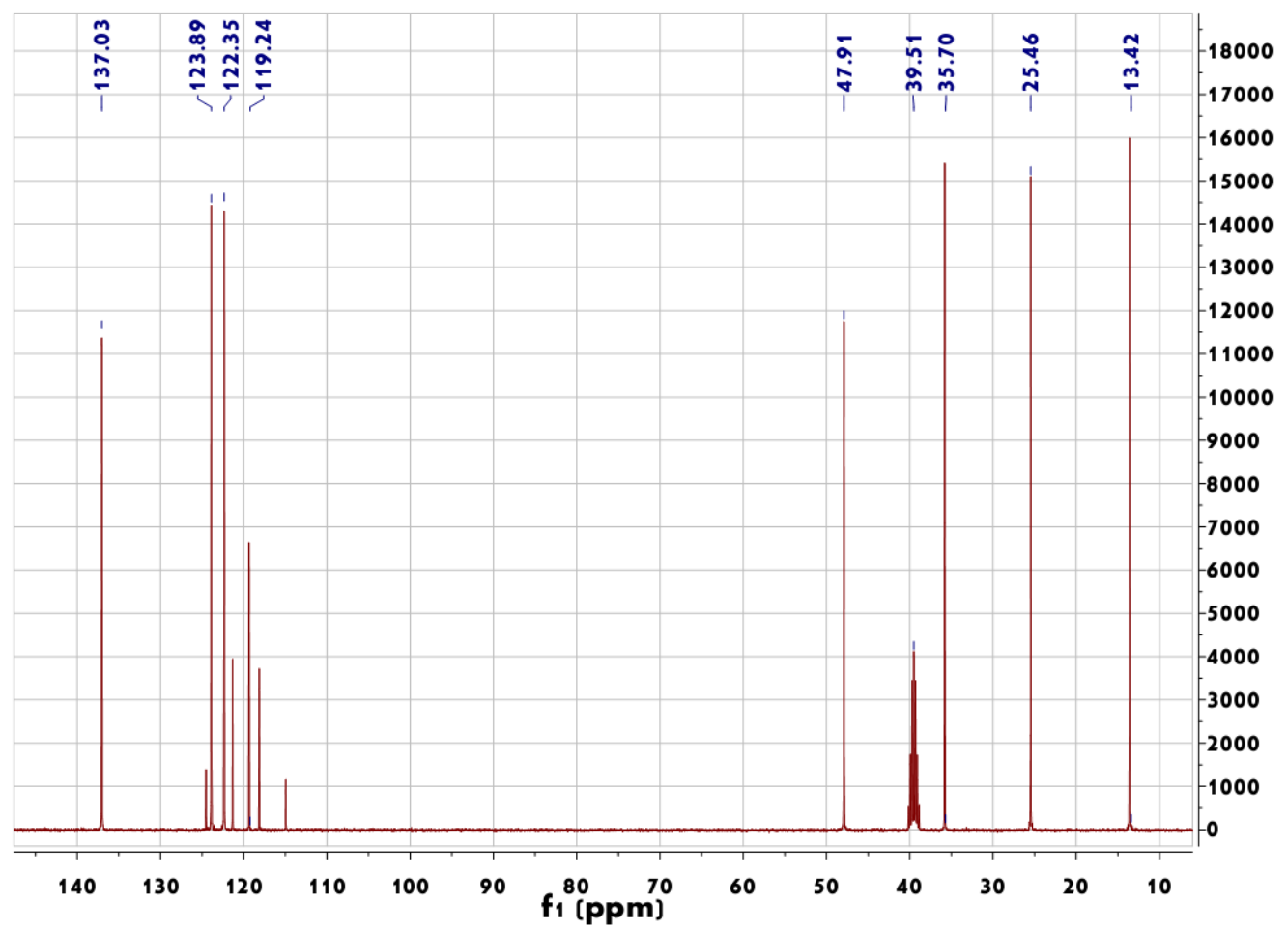

Fig.S2 ${ }^{13} \mathrm{C}$ NMR of [PCNMIM][NTf $\left.{ }_{2}\right]$ 